\title{
Transformasi Pemikiran Hukum Pidana Islam Terhadap Hukum Pidana Nasional (Analisis Implementatif Jarimah Hudud, Qishash dan Ta'zir)
}

\author{
Budi Dermawan ${ }^{1}$ dan M. Noor Harisudin ${ }^{2}$ \\ ${ }^{1}$ Fakultas Syariah, IAIN Jember. E-mail: budidermawan@gmail.com \\ ${ }^{2}$ Fakultas Syariah, IAIN Jember. E-mail: mnharisudinuinjember@gmail.com
}

\begin{tabular}{l}
\hline Article \\
\hline How to cite: \\
Budi Dermawan \& M. Noor \\
Harisudin, 'Transformasi \\
Pemikiran Hukum \\
Pidana Islam Terhadap \\
Hukum Pidana Nasional \\
(Analisis Implementatif \\
Jarimah Hudud, Qishash \\
dan Ta'zir)' (2020) Vol. 1 \\
No. 3 Rechtenstudent \\
Journal Fakultas Syariah \\
IAIN Jember.
\end{tabular}

Histori artikel:

Submit 3 September 2020;

Diterima 118 November

2020; Diterbitkan 7

Desember 2020.

ISSN:

2723-0406 (media cetak)

\section{Abstract}

National Criminal Law is currently felt that it does not fulfil the value of justice, certainty and legal usefulness in people's lives because of the number of criminal acts. That has recently occurred makes the law no longer a social control but instead uses the law as an opportunity to take action. Criminal law, this can be due to the lack of a deterrent effect caused by the criminal law itself. Many attempts have been made to implement Islamic criminal law in Indonesia. Still, it is poorly considered by the community because it is understood that Islamic criminal law is only partially understood. Whereas the purpose of Islamic criminal law is to maintain religion, reason, soul, descent and property for the sake of achieving justice, certainty and actual legal benefits. The focus of the problems in writing this thesis are 1). What are the concepts of Jarimah Qishash, Hudud, and Ta'zir in Islamic Criminal Law? 2). How is the Transformation of Jarimah Qishash, Hudud, and Ta'zir in Islamic Criminal Law Against National Criminal Law in Indonesia? The purpose of this research is to describe the concept of Jarimah Qishash, Hudud, and Ta'zir regarding Islamic Criminal Law. As well as to explain the Transformation of Jarimah Qishash, Hudud, and Ta'zir Against National Criminal Law. To identify some of these problems, this study uses a comparative approach method by comparing Islamic criminal law to national criminal law. Looking for similarities and differences in the two directions. Then combine it with the concepts used, then connect and dialogue with other ideas and then make interpretations and conclusions as a reflection of the author so that in the end, the research conclusions will be obtained.

Keywords: Transformation, Islamic Criminal Law, National Criminal Law.

\section{Abstrak}

Hukum Pidana Nasional pada saat ini dirasakan masih kurang memenuhi nilai keadilan, kepastian, dan kemanfaatan hukum dalam kehidupan masyarakat, disebabkan oleh banyaknya suatu tindak pidana yang terjadi akhir-akhir ini menjadikan hukum itu tidak lagi sebagai kontrol sosial melainkan memanfaatkan hukum sebagai kesempatan untuk berbuat tindak pidana, hal ini dapat disebabkan kurangnya efek jera yang ditimbulkan oleh hukum pidana itu sendiri. Banyak upaya yang telah dilakukan untuk menerapkan hukum pidana Islam di Indonesia tetapi memiliki anggapan yang buruk oleh masyarakat karena hal itu hukum pidana Islam hanya dipahami secara sepenggal. Padahal tujuan hukum pidana Islam memelihara agama, akal, jiwa, keturunan dan harta demi tercapainya keadilan, kepastian dan kemanfaatan hukum yang sebenar-benarnya. Fokus masalah dalam penulisan skripsi ini adalah: 1). Bagaimana Konsep Jarimah Qishash, Hudud, dan Ta'zir dalam Hukum Pidana Islam? 2). Bagaimana Transformasi Jarimah Qishash, Hudud, dan Ta'zir dalam Hukum Pidana Islam Terhadap Hukum Pidana Nasional di Indonesia? Tujuan dari penelitian ini adalah untuk mendeskripsikan konsep Jarimah Qishash, 
Hudud, dan Ta'zir terhadap Hukum Pidana Islam. Serta untuk menjelaskan Transformasi Jarimah Qishash, Hudud, dan Ta'zir Terhadap Hukum Pidana Nasional. Untuk mengidentifikasi beberapa permasalahan tersebut, penelitian ini menggunakan metode pendekatan komparatif dengan membandingkan hukum pidana Islam terhadap hukum pidana nasional. Mencari persamaan dan perbedaan di dalam kedua hukum tersebut. Kemudian memadukan dengan konsep-konsep yang digunakan, selanjutnya menghubungkan dan mendialogkannya dengan gagasan lain dan kemudian membuat interpretasi dan konklusi sebagai refleksi penulis sehingga pada akhirnya akan diperoleh simpulan penelitian.

Kata Kunci: Transformasi, Hukum Pidana Islam, Hukum Pidana Nasional.

\section{Pendahuluan}

Negara Indonesia adalah Negara hukum sebagaimana yang diatur dalam UndangUndang Negara Kesatuan Republik Indonesia Tahun 1945 amandemen ke empat khususnya dalam Pasal 1 ayat (3). ${ }^{1}$ Hal ini mengandung arti bahwa di dalam Negara Kesatuan Republik Indonesia (NKRI) hukum merupakan Panglima dan urat nadi pada segala aspek kehidupan dalam berbangsa dan bernegara. Jika kita berbicara tentang hukum, secara sederhana segera terlintas dalam pikiran kita adalah peraturan-peraturan atau seperangkat norma yang mengatur tingkah laku manusia dalam suatu masyarakat, baik peraturan atau norma itu berupa kenyataan yang tumbuh dan berkembang dalam masyarakat maupun peraturan atau norma yang dibuat dengan cara tertentu dan ditegakkan oleh penguasa. Citra mengenai hukum sudah dikenal pada masa kanak-kanak, manusia yang mula bermain dalam kelompok. Anak-anak sudah mampu membedakan permainan yang licik. ${ }^{2}$

Bentuknya beragam dimulai dari hukum yang tidak tertulis seperti hukum adat, dan juga berupa hukum tertulis sebagaimana yang tertuang dalam peraturan perundangundangan seperti hukum Barat. Di samping itu ada konsepsi hukum lain, di antaranya adalah konsepsi hukum Islam. Dasar dan kerangka hukumnya ditetapkan oleh Allah, tidak hanya mengatur hubungan manusia dengan manusia tetapi juga hubungan-hubungan lainnya, karena manusia yang hidup dalam masyarakat itu mempunyai berbagai hubungan. ${ }^{3}$

Sebelum kita berbicara tentang transformasi pemikiran hukum pidana Islam dalam hukum pidana nasional yang menjadi pusat perhatian dari pembahasan ini, kita harus memahami terlebih dahulu makna Islam, sebagai agama yang menjadi induk atau sumber dari hukum Islam itu sendiri. Sebabnya adalah karena berbeda dengan hukum Eropa yang memisahkan iman atau agama dari hukum, atau hukum dari kesusilaan. Dalam sistem hukum Islam pemisahan yang demikian tidak mungkin dilakukan karena selain hukum Islam itu bersumber dari agama Islam, juga sistem dalam ajaran Islam, hukum adalah bagian yang tidak dapat dipisahkan dari iman atau agama dalam arti sempit seperti dipahami dalam sistem hukum Eropa. ${ }^{4}$

Membicarakan hukum pidana Islam tidak dapat dilepaskan dari stigma pemikiran negatif oleh masyarakat secara umum. Miris sekali dalam hal ini tidak hanya dari umat yang berbeda agama melainkan umat yang menyandang agama Islam-pun berpikir negatif terhadap hukum pidana Islam, yang menganggap agama Islam dengan alasan kejam, keras,

\footnotetext{
${ }^{1}$ Udang-Undang Negara Republik Indonesia Tahun 1945 pasal 1 ayat (3)

2 Budiono Kusumohamidjojo, Filsafat Hukum, (Bandung: Mandar Maju, 2011), 14.

${ }^{3}$ Mohammad Daud Ali, Hukum Islam, 43.

${ }^{4}$ Ibid., 20-21.
} 
menyiksa dan tidak berperikemanusiaan. Sejak lama serangan terhadap Islam ditujukan terhadap permasalahan-permasalahan dengan sedemikian rupa. Ironisnya, seranganserangan tersebut bukan hanya dilakukan oleh para orientalis saja tetapi juga oleh sebagian kaum muslimin sendiri. ${ }^{5}$

Banyak orang menganggap bahwa hukum Islam yang dianut oleh bangsa Indonesia sama sekali masih bertentangan dan lebih rendah dari hukum modern yang diberlakukan oleh bangsa Belanda dan pemerintah jajahan. Anggapan itu biasanya didasarkan atas kemajuan masyarakat Belanda dalam peri-kehidupan modern khususnya di bidang teknik, industri, pelayaran dan perdagangan. Pada kenyataannya, kritik-kritik tersebut telah membuahkan hasil, setidaknya kini semakin sedikit kaum muslimin mempelajari hukum pidana Islam. Padahal ia adalah bagian integral dari sistem hukum Islam itu sendiri yang dianut hampir 90 persen rakyat Indonesia dan seperlima penduduk dunia. ${ }^{6}$

Pemikiran tersebut dikarenakan hukum pidana Islam belum dipahami dengan seksama sampai pada tahap pemikiran yang sempurna. Sering kali masyarakat luas menginterpretasikan hukum pidana Islam dengan setengah-setengah dan tidak dipahami secara benar dan secara menyeluruh. Pemikiran tersebut kemudian diperburuk dengan tidak diterapkannya hukum pidana Islam sebagai nilai-nilai yang memberikan sumbangsih terhadap pengaruh dalam kehidupan bernegara. Padahal hukum pidana Islam tidaklah lagi berkiblat kepada dunia Arab melainkan di Nusantara sendiri.

Distingsi Islam nusantara terkover dalam formulanya yang toleran, damai, sejuk dan inklusif sebagaimana terlihat dalam potret Indonesia dalam konteks dunia. Indonesia sebagai negara demokrasi Islam terbesar di dunia secara faktual telah menjadi ikon Islam Asia yang berbeda dengan Islam ala timur tengah yang keras dan kejam. Islam Indonesia hadir sebagai penyejuk dalam konteks pertikaian global. ${ }^{7}$

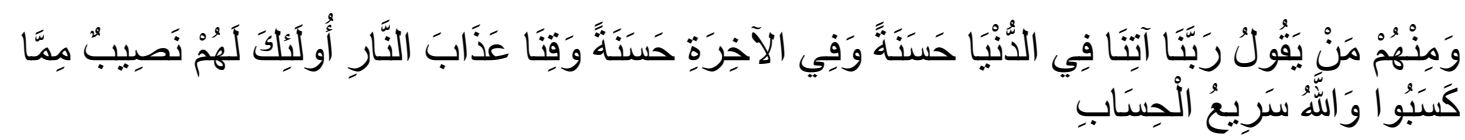

Artinya: dan di antara mereka ada yang berdoa, Ya Tuhan kami, berilah kami kebaikan di dunia dan kebaikan di akhirat, dan lindungilah kami dari azab neraka. Mereka itulah yang memperoleh bagian dari apa yang telah mereka pada kerjakan, dan Allah Maha cepat perhitungan-Nya. ${ }^{8}$

Dalam hukum Islam, tindak pidana (delik, jarimah) diartikan sebagai perbuatanperbuatan yang dilarang syara' yang diancam oleh Allah dengan hukuman hudud, qishash, atau ta'zir. ${ }^{9}$ Pemikiran hukum positif menitik-beratkan pada kepentingan manusia semata tanpa mendasari pada sakralitas ke-Tuhan-an. Hukum tidak mempunyai hubungan dengan psikologi, sosial, moral, dan ketuhanan. Hukum hanya mengatur kepentingan manusia di dunia dan tidak menjangkau kepentingan manusia di akhirat.

Pemikiran hukum acara jinayah adalah paradigma hukum syariah yang bersifat akomodatif terhadap materi Kitab Undang-Undang Hukum Acara Pidana. Pandangan ini perlu dipahami mengingat berkembang anggapan bahwa fikih tidak mengenal hukum acara,

\footnotetext{
${ }^{5}$ Topo Santoso, Menggagas Hukum Pidana Islam, (Bandung: Asy Syaamil Press \& Grafika, 2001), 13.

${ }^{6}$ Ibid., 14.

${ }^{7}$ M.Noor Harisudin, Membumikan Islam Nusantara. (Surabaya: Pena Salsabila, 2016), vii.

${ }^{8}$ Al-Qur'an, 2: 201-202.

${ }^{9}$ Zulkarnaen Lubis dan Bakti Ritonga, Dasar-Dasar Hukum Acara Jinayah, (Jakarta: Prenada Media Group, 2016$), 01$.
} 
dan apa yang dirumuskan dalam qanun hukum acara sepenuhnya copy-paste Kitab UndangUndang Hukum Acara Pidana. ${ }^{10}$ Bila menelisik antara banyaknya hukum maka dapat dilihat dari perbandingannya, yang mana perbandingan antara sistem hukum Islam dengan sistem hukum Adat dan eks-Barat. Ketiga sistem hukum dimaksud, akan dibandingkan mengenai apa yang kelihatan dan berlaku di Indonesia. Walaupun keadaan dan saat mulai berlakunya tidaklah sama baik pendekatan yuridis normatif maupun pendekatan yuridis empiris.

Di Indonesia hukum Islam tumbuh berkembang dengan pergulatan yang cukup lama. Akar genealogisnya dapat di tarik jauh ke belakang, yaitu sejak masuknya Islam pertama kali ke wilayah nusantara. Sepanjang sejarahnya, ia telah berinteraksi dan berdialektika dengan berbagai teologi, persoalan sosial, tasawuf, budaya, ekonomi, dan politik kebangsaan. ${ }^{11}$ Sedangkan Hukum Barat adalah hukum yang berasal dari hukum Romawi yang dianut oleh orang Eropa barat kontinental. Hukum yang dimaksud diperkenalkan oleh pemerintah kolonial Belanda ketika berdagang di Indonesia. ${ }^{12}$

Transformasi hukum pidana Islam ke dalam hukum pidana nasional hingga sampai sekarang ini masih memantik perdebatan di kalangan ahli. Baik dalam tataran teoretis maupun implementasinya. Selain itu upaya tersebut terkendala faktor baik eksternal maupun internal. ${ }^{13}$ Penulis berusaha untuk membawa pikiran hukum pidana Islam di transformasikan ke dalam hukum pidana nasional. Dengan jarimah yang sudah dimaksud yaitu $H u d u d$, Qishash dan Ta'zir.

Maka dalam hal ini supaya pembahasan ini tidak bias, maka penulis meringkas pembahasan yang sangat panjang tersebut menjadi sederhana, sehingga dapat dengan mudah untuk dipahaminya. Dalam jarimah hudud kejahatan yang dibahas adalah kejahatan pencurian. Pada jarimah qishash yang dibahas tentang adalah kejahatan pembunuhan. Sedangkan dalam jarimah ta'zir yang dibahas adalah seputar kejahatan korupsi. Ketiga jarimah ini mempunyai kelenturan dalam penerapannya yang dapat dijadikan sebagai bahan pembaharuan hukum pidana nasional. ${ }^{14}$

\section{Rumusan Masalah}

Adapun rumusan masalah dalam penelitian ini adalah:

1. Bagaimana Konsep Jarimah Qishash, Hudud, dan Ta'zir dalam Hukum Pidana Islam?

2. Bagaimana Transformasi Jarimah Qishash, Hudud, dan Ta'zir Terhadap Hukum Pidana Islam Terhadap Hukum Pidana Nasional?

\section{Metode Penelitian}

Jenis penelitian yang dipergunakan dalam penelitian ini, secara kategorikal termasuk dalam jenis penelitian kepustakaan (library research), yaitu dengan jalan melakukan penelitian terhadap sumber-sumber tertulis, maka penelitian ini bersifat kualitatif. Dalam penelitian ini dilakukan dengan mengkaji dokumen atau sumber tertulis seperti jurnal penelitian, disertasi,

\footnotetext{
${ }^{10}$ Ibid., 8.

${ }^{11}$ M.Noor Harisudin, Membumikan Islam Nusantara, 6-14.

12Zainuddin Ali, Hukum Islam Pengantar Ilmu Hukum Islam di Indonesia, (Jakarta: Sinar Grafika, 2018), 80.

${ }^{13} J u n a i d i$ Abdillah, Suryani, "Model Transformasi Fiqh Jinayah Ke Dalam Hukum Pidana Nasional", (Jurnal, Kritik Nazhariyat Al-' Uqu'bah Terhadap Materi KUHP), di unduh pada pada 29 Oktober, 2019), 98.

${ }^{14}$ Ridwan, Litimasi Hukum Pidana Islam, (Semarang: Wali Songo Press, 2008), 16.
} 
tesis, skripsi, laporan penelitian, buku teks, makalah, laporan seminar, diskusi ilmiah atau terbitan-terbitan resmi pemerintah dan lembaga-lembaga lain. ${ }^{15}$

Pendekatan yang dilakukan dalam penelitian ini adalah pendekatan komparatif (comparative appoarch) yakni sebuah pendekatan membandingkan hukum suatu negara dengan hukum negara lain atau hukum dari waktu tertentu dengan hukum dari waktu lain. ${ }^{16}$

\section{Hasil dan Pembahasan}

\section{Konsep Jarimah Hudud, Qishash, dan Ta'zir dalam Hukum Pidana Islam}

\section{a. Hudud}

Hudud secara bahasa hudud adalah jamak dari kata had yang berarti memisahkan salah satu barang agar tidak dapat tercampur dengan yang lain, atau salah satunya tidak melampaui batas atas yang lainnya. Kata ini juga dalam ensiklopedi Al-qur'an memberi makna batas atau sesuatu yang tajam, karena secara bahasa hadid berasal dari kata had. ${ }^{17}$ Dalam hal itu juga ada yang memberi makna sesuatu yang mencegah manusia untuk masuk. Dalam kamus besar bahasa Indonesia, kata had bermakna batas atau pembatasan. Hingga menghadkan dapat berarti pertama adalah membatasi, menentukan batasnya supaya tidak melebihi jumlah, ukuran, dan sebagainya. Kedua mengkhususkan. ${ }^{18}$

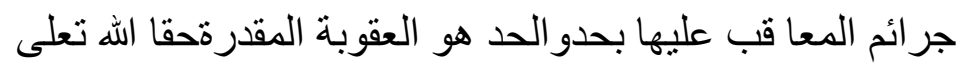

Artinya: Jarimah yang diancam padanya dengan hukuman hadd, dan hadd adalah hukuman yang telah ditentukan oleh Allah. ${ }^{19}$

Jumhur ulama' merumuskan jarimah hudud ada tujuh yang salah satunya ialah jarimah pencurian (sariqah). Sariqah (pencurian)di definisikan sebagai perbuatan mengambil harta orang lain secara diam-diam dengan maksud untuk memiliki serta tidak ada paksaan. Menurut Syarbini al-Khatib yang disebut pencurian adalah mengambil barang secara sembunyi di tempat penyimpanan dengan maksud untuk memiliki yang di lakukan dengan sadar atau adanya pilihan serta memenuhi syarat-syarat tertentu. ${ }^{20}$

Imam Ahmad berpendapat, mengenai pencurian, pertama harta tidak disyaratkan harus dengan kondisi disimpan dan terjaga atau diletakkan di tempat yang pantas. Hukuman tetap dijatuhkan bagi pencuri meskipun harta yang dicuri diletakkan di berbagai tempat. Di samping itu, tidak ada penjelasan dari Hadis Nabi Saw. yang menyatakan bahwa syarat dilaksanakan hukuman pencurian berlaku bagi harta yang dicuri dari tempat penyimpanan khusus yang disimpan aman. Kedua, mayoritas ulama imam mazhab seperti: Imam Hanafi, Imam Malik, dan Imam Syafi'i berpendapat bahwa harta yang dicuri yang bisa menyebabkan had potong tangan, disyaratkan harus disimpan dengan baik dan terjaga. Salah satu kriteria harta yang dicuri adalah harta yang diambil bukan miliknya, harta diambil dengan cara sembunyi-sembunyi, dan ada niatan jahat. Selain itu, harta yang dicuri diletakkan pada suatu tempat yang pantas dan memang sengaja untuk disimpan. Rasa tersebut untuk dapat membedakan antara harta temuan (luqatah) dengan harta hasil curian (sariqah).

\footnotetext{
15 Tim penyusun, pedoman, 78-79.

16 Ibid., 172.

17 Sahabuddin, Ensiklopidia Al-Qur'an, (Jakarta: Lentera Hati, 2007), 263.

${ }^{18}$ Kamus Besar Bahasa Indonesia, (Jakarta: Balai Pustaka, 1988), 290.

${ }^{19}$ Abdul Qadir Audah, al-Tasyri, al-Jina'i al-Islami, (Beirut: Muasasah al-Risalah, 1992), 78.

${ }^{20}$ Syarbini al-Khatib, Mughni Al-Muhtaj, (Mesir: Dar al-bab al-Halabi wa awladuhu, 1978), 158.
} 
a) Imam al-Syafi'i berpendapat, nishab untuk harta pencurian adalah $1 / 4$ dinar emas, atau yang serupa dengannya. Misalnya 3 dirham. Imam Al-Nawawi mengatakan: inilah pendapat mayoritas ahli fikih yang bersumber dari perkataan Aisyah r.a. Umar bin Abd Aziz, al-Awza'i, al-Laits bin Sa'id, Ishaq bin Rahawaih, dan begitu juga riwayat Daud al-Zhahiri. Dalam riwayat yang bersumber dari Ja'far bin Muhammad disebutkan, Imam Ali memberikan sanksi potong tangan kepada pencuri yang mencuri $1 / 4$ dinar di mana nilainya sama dengan $2 \frac{1}{4} 4$ dirham..$^{21}$

a. Qishash

Secara literal, qishash merupakan kata turunan dari qashsha yaqushshu qashshan wa qashashan yang berarti menggunting, mendekati, menceritakan, mengikuti (jejaknya) dan membalas. ${ }^{22}$ Dalam al-Qur' an terdapat makna qishash sebagai "mengintai atau mengikuti jejak

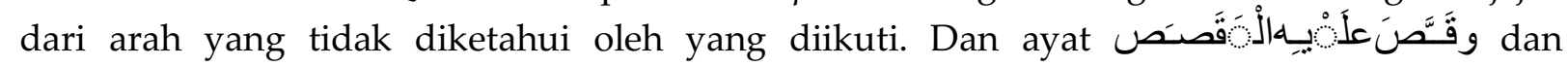
menceritakan kepadanya cerita tentang mengenai dirinya. Sementara qishash sendiri bermakna تتبع الـدمبالقود artinya mengikuti /membalas penumpahan darah dengan bentuk perbuatan yang serupa. ${ }^{23}$

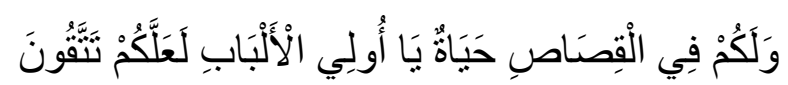

Artinya: dan dalam qishash itu ada jaminan kelangsungan kehidupan bagimu,

wahai orang-orang yang berakal, supaya kamu bertakwa. ${ }^{24}$

Ulama mazhab Malikiyah dan Syafi'iyah memaknai ayat tentang jarimah qishash tersebut mengandung arti al-mumatsalah dalam pelaksanaannya, Maka pelaksanaan hukum pembunuhan disesuaikan dengan sifat dan cara bagaimana ia melakukan pembunuhan tersebut, maka jika seseorang membunuh dengan cara menenggelamkan, maka pelakunyapun harus dapat di qishash dengan cara menenggelamkannya. Siapa yang membunuh dengan alat serupa batu, maka dibunuh dengan cara batu juga

Sementara mazhab Hanafiyah dan Hanabilah berpendapat bahwa yang dituju dalam penerapan qishash tersebut adalah jiwa dengan jiwa, maka dengan cara apapun ia membunuh, maka pelaku pun di qishash dengan benda tajam (pedang). Pendapat ini didasarkan pada hadits Al-nu'man bin Basyir yang diriwayatkan Ibn Majah dan al-Baihaqy, bahwa Rasulullah

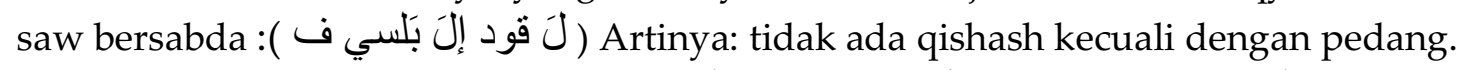

جر ا نم التي يعا قب عليها بقصاص اوديه وكل من قصاص الدية عقوبة مقدرة حقالافر اد

Artinya: Jarimah yang diancam kepadanya hukuman qishash atau diat adalah hukuman yang telah ditentukan batasannya dan menjadi hak perseorangan..$^{25}$

Mengenai pelaksanaan hukuman qishash, banyak timbul perbedaan pendapat di antara para ulama, apakah sifat pelaksanaan hukuman qishash sama seperti yang dilakukan oleh si pelaku dalam hal ini pembunuh, apakah cukup dengan menghilangkan nyawanya saja. Yaitu membunuh dengan memenggal batang lehernya dengan pedang. Imam Malik telah berkata bahwa jika membunuh menggunakan batu balas dengan bunuh pakai batu, jika dengan tongkat balas sama dengan tongkat, mencekik dengan mencekik, ditenggelamkan ya

\footnotetext{
21 Makhrus Munajat, “Transformasi Norma-Norma Hukum Pidana Islam Dalam Upaa Pembaharuan Hukum Pidana Nasional", (Disertasi, Universitas Islam Indonesia, yogyakarta, 2009), 70.

22 M.Quraisy Shihab, Tafsir al-Misbah Pesan dan Keserasian Al-qur'an, (Jakarta: Lentera Hati, 2001), 108.

${ }^{23}$ Ahmad Warson Munawwir, Al-Munawwir Kamus Arab-Indonesia, (Yogyakarta: Pondok Pesantren al-Munawwir, 1984), 1210.

${ }^{24}$ Ibid., 2: 179.

${ }^{25}$ Abdul Qadir Audah, al-Tasyri, al-Jina'i al-Islami, 79.
} 
ditenggelamkan. Rasul pernah memerintahkan kepala yahudi itu di antara dua buah batu lalu dibunuh dengan pedang, berikut ditiru oleh para penerusnya.

Menurut imam Syafi'i jika seseorang mencampakkan orang lain ke dalam api sampai mati, maka campakkan juga ke dalam api sehingga mati, jika membunuh menggunakan batu maka walinya yang melemparkan batu sampai mati juga, jika tidak mati dengan beberapa pukulan maka dibunuh dengan pedang. Apabila pembunuhan dilakukan dengan sihir maka di qishash dengan pedang. ${ }^{26}$

\section{b. Ta'zir}

Menurut bahasa lafaz ta'zir berasal dari kata $a^{\prime} z z a r a$ yang sinonimnya berarti mencegah dan menolak, yang artinya mendidik. Pengertian tersebut di atas sesuai dengan apa yang dikemukakan oleh Abdul Qadir Audah dan Wahbah az-Zuhaily bahwa pidana ta'zir diartikan sebagai upaya mencegah dan menolak karena ia dapat mencegah pelaku agar tidak mengulangi perbuatannya lagi. Sedangkan $t a^{\prime} z i r$ diartikan sebagai mendidik karena $t a^{\prime} z i r$ dimaksudkan untuk mendidik dan memperbaiki pelaku kejahatan agar Ia menyadari perbuatan jarimahnya kemudian meninggalkan dan menghentikannya.

$$
\text { و التعزيرتاءديب عل ذنوب لمم تشرع فيها الحدود }
$$

Artinya: Ta'zir adalah hukuman pendidikan atas dosa (tindak pidana) yang belum ditentukan hukumannya oleh syara. ${ }^{27}$ Dalam suatu riwayat bahwa Umar bin Khathab radhiyallahu 'anhu menta'zir dan memberi pelajaran terhadap seseorang dengan mencukur rambut, mengasingkan dan memukul pelakunya, pernah pula beliau radhiyallahu 'anhu membakar kedai-kedai penjual khamr dan membakar suatu desa yang menjadi tenpat penjualan khamr. Ta'zir dalam perkara yang disyariatkan adalah $t a^{\prime} z i r$ yang wajib menurut pendapat Imam Abu Hanifah, Imam Malik dan Imam Ahmad rahimahumullah.

Hukuman $t a^{\prime} z i r$ adalah hukuman yang pelaksanaannya diserahkan sepenuhnya kepada penguasa. Hukuman $t a^{\prime} z i r$ dijatuhkan dengan mempertimbangkan berat ringannya suatu tindak pidana, situasi dan kondisi masyarakat, serta tuntunan kepentingan umum. Hal ini dapat dikatakan bahwa hukuman ta'zir diterapkan tidak secara definitif, melainkan masih meliliat situasi dan kondisi terlebih dahulu, dan bagaimana perbuatan jarimah terjadi, kapan waktunya, siapa korbannya, dan sanksi apa yang pantas dikenakan demi menjamin ketentraman dan kemaslahatan umat. Dari pengertian tersebut dapat dirumuskan tentang pembagian tindak pidana dalam Islam. ${ }^{28}$

\section{Transformasi Jarimah Hudud, Qishash dan Ta'zir Terhadap Hukum Pidana Nasional}

Untuk bisa melakukan transformasi hukum pidana Islam, umat Islam di Indonesia harus terus-menerus mengembangkan model-model pembumian hukum pidana Islam dengan menggalinya dari pengalaman sejarah bangsa Indonesia itu sendiri maupun dari pengalaman bangsa-bangsa lain. Transformasi hukum pidana Islam di Indonesia perlu mempertimbangkan masyarakat Indonesia yang multi kultur, multi etnik, dan multi

\footnotetext{
${ }^{26}$ Haliman, Hukum Pidana Syari'at Islam Menurut Ajaran Ahlus Sunnah, (Jakarta: Bulan Bintang, 1971), $282-285$.

${ }^{27}$ Ahmad Wardi Muslich, Fikih Jinayah, 19.

28 Makhrus Munajat, “Transformasi Norma-Norma Hukum Pidana Islam Dalam Upaya Pembaharuan Hukum Pidana Nasional”, (Disertasi, Universitas Islam Indonesia, yogyakarta, 2009), 61.
} 
mazdhab. Transformasi mesti tidak hanya berujung pada proses formalisasi tetapi juga pada proses internalisasi. Apabila suatu proses internalisasi berjalan baik, maka hukum pidana Islam akan masuk kedalam kesadaran masyarakat muslim sebagai kesadaran etik dan moral. Sehingga pada level privat hukum pidana Islam akan diamalkan dan menjadi way of life terlepas apakah ia diformalkan dalam undang-undang atau tidak.

Untuk mengembangkan proses transformasi hukum pidana Islam ke dalam supremasi hukum pidana nasional, banyak memerlukan partisipasi semua pihak dan lembaga terkait, seperti halnya hubungan hukum pidana Islam dengan badan kekuasaan negara yang mengacu kepada kebijakan politik hukum yang ditetapkan. Politik hukum tersebut merupakan bentuk produk interaksi kalangan elite politik yang dapat berbasis kepada berbagai kelompok sosial budaya. Ketika elite politik Islam memiliki daya tawar yang kuat dalam interaksi politik itu, maka ada peluang bagi pengembangan hukum pidana Islam untuk ditransformasikan semakin besar. Transformasi hukum Islam ke dalam hukum nasional dapat terjadi dalam berbagai peraturan perundang-undangan, terutama hukum perdata. Kemudian proses transformasi hukum Islam dilakukan dengan memasukkan asas-asas hukum Islam ke dalam hukum nasional. Transformasi asas-asas tersebut tanpa menggunakan label hukum Islam, tetapi diserap dalam hukum nasional. Transformasi hukum Islam dalam pembentukan hukum nasional juga dapat dilakukan dalam bentuk produk pengadilan, baik melalui pengadilan agama maupun pengadilan umum..$^{29}$

Hukum pidana Islam sering mendapat tudingan sebagai hukum yang out of date dan dehumanis. Tudingan itu terjadi karena ketidaksanggupan mereka menangkap ruh syari'at Islam. Padahal hukum pidana lslam sebagaimana yang tertera dalam nas tidaklah absolut. Nabi tidak selalu memberlakukan hukum sebagaimana bunyi teks tetapi sangat kondisional. Hukum pidana Islam bukanlah bersifat hukum yang bersifat ortodoks melainkan memberikan ruang gerak bagi akal fikiran manusia untuk selalu ijtihad. ljtihad ini diberikan dalam rangka menafsirkan teks-teks hukum sehingga mampu merespons kebutuhan dan tuntutan masyarakat yang sangat dinamis. Oleh karena itu perlu diadakan reaktualisasi pemikiran hukum pidana lslam terutama dari sisi klasifikasi tindak pidana sampai kepada persoalan semacam sanksi. Sistem hukum pidana lslam sesungguhnya diawali dengan koreksi terhadap sistem hukum Jahiliyah yang diskriminatif pada zamannya. Kabilah yang kuat di kala itu sangat berhak dalam persoalan intervensi hukum, sementara suku yang lemah hanya sebagai pelengkap penderita seperti halnya kaum tertindas karena ketidakberdayaannya. Islam datang dengan membawa panji menegakkan hukum dengan prinsip keseimbangan serta keadilan. ${ }^{30}$

Transformasi mempunyai berbagai makna yaitu mengubah rupa, sifat, bentuk berupa fisik, fungsi atau mengalihkan. Arti transformasi hukum pidana Islam ke terhadap hukum pidana nasional di sini, yaitu perubahan rupa, bentuk atau sifat atau mengalihkan hukum Islam (diubah, dialihkan dan disumbangsihkan) kepada hukum nasional, sehingga hukum pidana Islam itu tidak saja milik orang Islam, tetapi hukum pidana Islam itu milik nasional

\footnotetext{
${ }^{29}$ Cik Hasan Bisri, Peradilan Agama di Indonesia, (Jakarta: PT Raja Grafindo Persada, 1998), 86.

30 Makhrus Munajat, “Transformasi Norma-Norma Hukum Pidana Islam Dalam Upaa Pembaharuan Hukum Pidana Nasional”, (Disertasi, Universitas Islam Indonesia, yogyakarta, 2009), 63.
} 
(Indonesia) akibatnya menjadi hukum nasional dengan menggunakan kerangka teori transformasi hukum pidana Islam terhadap hukum pidana nasional atau teori pembinaan hukum nasional sebagai pisau analisis. Adapun hukum nasional yaitu peraturan yang dibuat oleh pemerintah dalam hal ini adalah eksekutif bersama-sama dengan badan legislatif yang berlaku bagi semua orang di suatu masyarakat (nagara). ${ }^{31}$

Posisi hukum Islam selalu menarik perhatian untuk menjadi topik pembicaraan, dimana ada penganutnya, maka ruang itu akan terisi bangunan dan sistem hukum akan terbentuk. Sebab hukum Islam mengikuti dimana orang itu berada. Sebagaimana asas personalitas keIslaman. Bahtiar Effendy menulis ciri Islam yang paling menonjol, yaitu sifatnya yang dapat hadir di mana-mana (omnipresence). Ini sebuah pandangan yang mengakui bahwa di mana kehadiran Islam selalu memberikan panduan moral yang benar bagi perbuatan setiap manusia. $^{32}$

Mengingat negara Indonesia sekarang ini sedang melaksanakan agenda reformasi hukum nasional, dan hukum Islam merupakan bagian atau sub sistem hukum nasional, maka hukum Islam perlu dijadikan obyek penelaahan, sehingga agenda pembaruan atau reformasi hukum nasional juga mencakup pengertian pembaruan terhadap hukum Islam itu sendiri, dengan memperhitungkan faktor sistem hukum Islam yang dapat ditransformasikan ke dalam hukum nasional menuju masa depan yang diharapkan akan menjadikan hukum Islam sebagai suatu kesatuan sistem yang supreme dalam wadah Negara Kesatuan Republik Indonesia (NKRI). Dengan demikian, hukum Islam sebagai hukum yang hidup dan berkembang di masyarakat memiliki ciri khas tersendiri, di antaranya adalah hukum Islam bercorak responsif, adaptif serta dinamis. ${ }^{33}$

\section{Implementasi Hukum Pidana Islam Terhadap Hukum Pidana Nasional}

Pada umumnya para ulama membagi fiqh jinayah pada dua bagian besar, yakni: jenis perbuatan pidana (jarimah) dan jenis hukuman yang ditimpakan ('uqubah). Sedangkan menyangkut keadaan pelaku (subjek/pertanggungjawaban pidana) umumnya menjadi satu bagian dari pembahasan jenis perbuatan pidana, walaupun bahasan subjek tidak dipisah secara tersendiri, tetapi tetap masuk menjadi bagian dari ruang lingkup yang dibahas dalam hukum pidana Islam, yakni menyangkut jenis perbuatan pidana dan jenis hukumannya. ${ }^{34}$

Dapat diakui publik bahwa menjadikan hukum Islam sebagai bagian dari hukum nasional dalam konteks hukum di Indonesia, bukanlah pekerjaan yang mudah. Karena, hukum yang berlaku di Indonesia adalah sistem hukum Eropa kontinental yang dipelopori Prancis seperti Belanda, Jerman dan Swiss. Indonesia yang menjadi jajahan negara Belanda pada akhirnya juga mengikuti hukum negara penjajahnya. Oleh sebab itu, upaya Hazairin patut diapresiasi sebagai bagian perjuangan kalangan Islam untuk menempatkan hukum Islam

\footnotetext{
31 A.Khisni, Transformasi Hukum Islam Kedalam Hukum Nasional, (Semarang: UNISSULA Press, 2011), 227.

${ }^{32}$ Bahtiar Effendy, Islam dan Negara Transformasi Pemikiran dan Praktek Politik di Indonesia, (Jakarta: Paramadia, 1998), 7.

${ }^{33}$ Amir Mu'allim dan Yusdani, Konfigurasi Pemikiran Hukum Islam, (Yogyakarta: UII Press, 2001), 15.

${ }^{34}$ Asep Saepudin Jahar dan Euis Nurlaelawati-Jaenal Aripin, Hukum Keluarga, Pidana \& Bisnis Kajian Perudangundangan Indonesia, (Jakarta: Kencana, 2013), 114-115.
} 
Pada tempat yang proporsional. ${ }^{35}$ Mengenai peran hukum Islam dalam pembaharuan hukum pidana sangat penting. Jimly Asshiddiqie mengatakan: bila dilihat dari satu segi, hukum Islam perlu dijadikan objek penelaahan sehingga agenda pembaruan atau reformasi hukum nasional juga mencakup pengertian pembaruan terhadap hukum Islam itu sendiri. Tetapi di pihak lain sistem hukum Islam itu sendiri dapat pula berperan penting dalam rangka pelaksanaan agenda reformasi hukum nasional sebagai keseluruhan. Jangan sampai, misalnya, karena kesibukan kita memikirkan keseluruhan sistem hukum nasional yang perlu direformasi, menyebabkan kita lalai memperhitungkan faktor sistem hukum Islam yang sangat penting, artinya dalam keseluruhan pengertian sistem hukum nasional yang sedang mengalami proses transformasi menuju ke masa depan yang diharapkan akan menjadikan hukum sebagai satu kesatuan sistem yang supreme dalam wadah Negara Kesatuan Republik Indonesia. ${ }^{36}$

Dilihat dari segi berat dan ringannya pidana, bahwa pidana cambuk sebagai bentuk pidana badan (corporal punishment) tentu lebih ringan daripada pidana mati yang merampas jiwa seseorang, pidana penjara yang merampas kemerdekaan seseorang, pidana kurungan yang merampas kemerdekaan seseorang, maupun denda yang merampas harta seseorang. Dilihat dari segi ekonomis pidana, maka bahwa pidana cambuk sebagai bentuk pidana badan (corporal punishment) lebih murah daripada pidana mati dan pidana penjara. Ditinjau dari segi teori pemidanaan, bahwa pidana cambuk sebagai bentuk pidana badan (corporal punishment) cenderung kepada teori relative atau teori tujuan yang memandang pidana bukanlah pembalasan terhadap orang yang melakukan kejahatan, tetapi sebagai sarana untuk melindungi kepentingan masyarakat, karena dengan adanya bahwa pidana cambuk sebagai bentuk pidana badan (corporal punishment) diharapkan muncul efek jera sehingga tidak akan terjadi pengulangan tindak pidana. ${ }^{37}$

Mungkinkah hukum pidana Islam dapat diberlakukan sebagaimana aspek hukum Islam di bidang keperdataan yang telah berlaku di Indonesia selama ini? Sebagaian orang-orang akan menolak mentah-mentah berbaga gagasan soal hukum pidana Islam dalam hukum nasional. Penolakan ini akan hampir sama dengan penolakan sekelompok komunis yang dahulu ada di Negeri ini. Akan tetapi menurut Topo Santoso berpendapat sebaliknya tentang masalah ini yang mengungkap bahwa gagasan tersebut sangat relevan dan ilmiah jika kita tinjau secara objektif dan jujur. Sebagai satu bidang kajian seharusnya kita tida boleh alergi akan hukum pidana Islam tersebut. Kalau kita bicara studi berbandingan, objektif, dibahas semua, Islamic law sebagai keluarga hukum sama seperti civil law dan common law.

\section{Peluang dan Tantangan Hukum Pidana Islam Terhadap Hukum Pidana Nasional}

1) Hukum Islam diakui dan memiliki kedudukan penting dalam perundang-undangan di Indonesia, baik sebagai sumber utama, penyaring, maupun sebagai hukum yang berdiri sendiri. Meskipun secara konstitusi, negara Indonesia bukan negara

\footnotetext{
${ }^{35}$ M. Noor Harisudin, “Diskursus Fikih Indonesia: Dari Living Laws Menjadi Positive Laws”, (Jurnal, Al- Manahij, Vol. 10, No.2) di unduh pada Desember 2016), 173- 174.

36 Dwiyana Achmad Hartanto, "Kontribusi Hukum Islam Dalam Pembaharuan Hukum Pidana di Indonesia", (Jurnal, ILMU SYARI'AH DAN HUKUM, Vol. 1), di unduh pada 2016), 187.

${ }^{37}$ Dwiyana Achmad Hartanto, Kontribusi Hukum Islam, 198-190.
} 
berdasarkan Islam, tetapi Pancasila sebagai falsafah negara tetap memberi peluang yang besar masuknya aturan yang bersumber dari agama Islam. Perkembangan teori hukum di Indonesia memperkokoh posisi strategis hukum islam sebagai sumber perundang-undangan di Indonesia. Fiqh Nusantara merupakan fiqh yang berkembang di lingkungan Nusantara dengan karakternya yang khas sesuai dengan adat-istiadat keindonesiaan. ${ }^{38}$

2) Mengangkat harkat dan martabat manusia, melalui penegakan hukum, prinsip persamaan dan kemerdekaan, yakni setiap manusia wajib menjunjung tinggi hukum, menaati prinsip persamaan dan kemerdekaan, sehingga tidak seorang pun yang dapat merebut hak orang lain, baik dari segi aspek hukum dan aspek pemerintahan. Menurut pandangan Islam bahwa kemerdekaan itu adalah hak setiap orang, maka perbudakan itu harus dihapuskan karena tidak sesuai dengan perikemanusiaan dan perikeadilan. Pada muqaddimah UUD-1945 dinyatakan bahwa kemerdekaan itu adalah hak segala bangsa kerena itu penjajahan harus dihapuskan karena tidak sesuai dengan perikemanusiaan dan perikeadilan. ${ }^{39}$

3) Mengharmonisasikan hubungan dalam kehidupan manusia pada layaknya, melalui pembinaan persaudaraan, ukhuwah dan persatuan, serta berlaku sopan terhadap mereka yang beragama lainnya, sebelum menerima Islam sebagai keyakinan yang toleran

4) Memberikan perlindungan terhadap hak-hak Allah dan hak asasi manusia dalam bentuk memberi perlindungan terhadap jiwa, agama, kehormatan, akal, dan harta benda, serta memelihara keamanan, dan ketenteraman bangsa dan Negara yang melalui pengawasan teritorial dan penegakan hukum secara adil

Tantangan Hukum Pidana Islam Terhadap Hukum Pidana Nasional

1) Umat Islam masih ada yang turut fobia terhadap hukum pidana Islam dan beranggapan hukum pidana Islam tidak cocok dengan zaman sekarang, serta ragu pada efektivitas hukum pidana Islam ketika diterapkan dalam masyarakat majemuk seperti di Indonesia

2) Umat Islam yang setuju dengan penerapan hukum pidana Islam belum menyatu pada satu metode penerapan tertentu, bahkan terkadang satu pihak mengklaim metodenya sebagai satu-satunya metode yang paling begitu efektif. Misalnya satu pihak mengklaim, bahwa untuk menegakkan hukum pidana Islam, terlebih dahulu melalui pembentukan negara Islam, ada kelompok mengklaim mesti dengan para kekhalifahan Islam, seperti masa lalu, dan pihak lainnya memilih langsung melakukan tindakan memberantas maksiat dengan merusak tempat-tempat yang dicurigai digunakan bermaksiat. ${ }^{40}$

${ }^{38}$ M. Noor Harisudin, “'Urf Sebagai Sumber Hukum Islam (Fiqh) Nusantara”, (Jurnal aL-FIKR Volume 20 Nomor 1), di unduh pada 2016), 67

39 UUD 1945, Pembukaan Alinea Empat

40 Topo Santoso, Menggagas Hukum Pidana Islam, (Bandung: Al-Syamil Press, 2000), 9. 
3) Kendala kultural atau sosiologis, yakni adanya umat Islam yang masih belum bisa menerima hukum Islam sepenuhnya.

4) Kendala fikrah (pemikiran), yaitu banyaknya pandangan negatif terhadap hukum pidana Islam dan kurang yakin dengan efektivitasnya.

\section{Kesimpulan}

Bila ditinjau dari segi macamnya jarimah yang diancamkan hukuman, terdapat jarimah hudud, qishash, dan ta'zir. Hudud merupakan suatu jarimah yang diancam dengan hukuman hadd, dan hadd adalah hukuman yang telah ditentukan oleh Allah. Swt. Adalah kejahatan pencurian yang diancam dengan hukuman potong tangan. Qishash merupakan kata turunan dari qashsha yaqushshu qashshan wa qashashan yang berarti menggunting, mendekati, menceritakan, mengikuti (jejaknya) dan membalas penumpahan darah dengan bentuk perbuatan yang serupa. Yaitu kejahatan pembunuhan yang diancam dengan pembunuhan serupa. Sedang $t a^{\prime} z i r$ merupakan hukuman yang belum ditetapkan oleh syara' dan wewenang untuk menetapkannya diserahkan kepada ulil amri. Yaitu kejahatan korupsi yang diancam dengan hukuman sesuai ketetapan putusan hakim. Serta terdapat faktor-faktor yang dapat mempengaruhi terhapusnya pertanggung jawaban suatu jarimah, yang salah satunya ialah pengaruh tidak tahu, unsur paksa dan pembelaan diri.

Hukum pidana Islam sering mendapat tudingan sebagai hukum yang out of date dan dehumanis. Dalam transformasi ini, hukum pidana Islam akan senantiasa bersikap antisipatif terhadap perkembangan sosial, dan dalam perkembangan selanjutnya hukum Islam memberikan nilai andil yang cukup besar bagi pembangunan hukum nasional. Pengaruh politik kenegaraan terhadap hukum Islam sangat signifikan, banyak perundang-undangan yang berlabel Islam, karena ini terjadi adanya hubungan kerjasama antara ulama' dengan umara' dalam menjalankan fungsi dan tugas masing-masing. Terdapat beberapa nilai-nilai hukum pidana Islam yang ditransformasikan pada hukum pidana nasional yaitu dengan agenda rancangan kitab undang-undang hukum pidana yang masih direvisi sampai sekarang.

\section{Daftar Pustaka}

\section{Buku}

Al-Khatib, Syarbini .1978.Mughni Al-Muhtaj, Mesir: Dar al-bab al-Halabi wa awladuhu Bisri, Cik Hasan .1998. Peradilan Agama di Indonesia, Jakarta: PT Raja Grafindo Persada

Darmawan, Deni. 2014. metode penelitia kualitatif, Bandung: PT. Rosdakarya

Daud Ali, Mohammad. 2014. Hukum Islam Pengantar Ilmu Hukum Dan Tata Hukum Islam Di Indonesia. Jakarta: Rajawali Pers

Effendy, Bahtiar. 1998. Islam dan Negara Transformasi Pemikiran dan Praktek Politik di Indonesia, Jakarta: Paramadia

Haliman. 1971.Hukum Pidana Syari'at Islam Menurut Ajaran Ahlus Sunnah, Jakarta: Bulan Bintang

Harisudin, M. Noor. 2016. Membumikan Islam Nusantara. Surabaya: Pena Salsabila.

Jahar, Asep Saepudin dan Euis Nurlaelawati-Jaenal Aripin. 2013. Hukum Keluarga, Pidana \& Bisnis Kajian Perudang-undangan Indonesia, Jakarta: Kencana, 2013

Kamus Besar Bahasa Indonesia, 1998. Jakarta: Balai Pustaka

Khisni, Ahmad.2011. Transformasi Hukum Islam Kedalam Hukum Nasional, Semarang: UNISSULA Press 
Kusumohamidjojo, Budiono. 2011.Filsafat Hukum, Bandung: Mandar Maju

Lubis, Zulkarnaen dan Bakti Ritonga. 2016. Dasar-Dasar Hukum Acara Jinayah. Jakarta: Prenada Media Group

Mahmud Marzuki, Peter.2016. Penelitian Hukum, Jakarta: Prenamedia Group

Moleong, Lexy J. 2010. metode penelitian kualitati, Bandung: PT Remaja Rosdakarya

Mu'allim, Amir dan Yusdani.2001. Konfigurasi Pemikiran Hukum Islam, Yogyakarta: UII Press

Munawwir, Ahmad Warson .1984.Al-Munawwir Kamus Arab-Indonesia, Yogyakarta: Pondok Pesantren al-Munawwir

Qadir Audah, Abdul. 1992. al-Tasyri, al-Jina'i al-Islami, Beirut: Muasasah al-Risalah

Ridwan. 2008. Litimasi Hukum Pidana Islam, Semarang: Wali Songo Press

Saebani, Beni Ahmad. 2008. Metode penelitian hukum, Bandung: CV Pustaka Setia

Sahabuddin. 2007. Ensiklopidia Al-Qur'an, Jakarta: Lentera Hati

Santoso, Topo. 2001. Menggagas Hukum Pidana Islam. Bandung: Asy Syaamil Press \& Grafika.

Shihab, M.Quraisy .2001.Tafsir al-Misbah Pesan dan Keserasian Al-qur'an, Jakarta: Lentera Hati

Tim Penyusun. 2019. Pedoman Penulisan Karya Ilmiah. Jember: IAIN Jember Press

\section{Jurnal}

Abdillah, Junaidi, 2019. "Model Transformasi Fiqh Jinayah Ke Dalam Hukum Pidana Nasional (Kritik Nazhariyat Al-' Uqu'bah Terhadap Materi KUHP)", (Jurnal, diunduh pada 29 Oktober 2019).

Achmad Hartanto, Dwiyana. 2016 “Kontribusi Hukum Islam Dalam Pembaharuan Hukum Pidana di Indonesia", (Jurnal, ILMU SYARI'AH DAN HUKUM, Vol. 1), di unduh pada 2016

Harisudin, M. Noor. 2016.Diskursus Fikih Indonesia: Dari Living Laws Menjadi Positive Laws", (Jurnal, Al- Manahij, Vol. 10, No.2) di unduh pada Desember 2016

Munajat, Makhrus. 2009.Transformasi Norma-Norma Hukum Pidana Islam Dalam Upaa Pembaharuan Hukum Pidana Nasional, Disertasi, Universitas Islam Indonesia, yogyakarta 